\title{
PENGARUH MODAL PSIKOLOGIS, KARAKTERISTIK WIRAUSAHA, MODAL USAHA DAN STARTEGI PEMASARAN TERHADAP PERKEMBANGAN USAHA UMKM DI KECAMATAN BULELENG TAHUN 2017
}

\author{
Diota Prameswari Vljaya, M. Rudi Irwansyah \\ Jurusan Akuntansi Program S1 \\ Universitas Pendidikan Ganesha \\ Singaraja, Indonesia \\ e-mail: diota.pv@gmail.com, rudi.irwansyah@undiksha.ac.id
}

\begin{abstract}
Abstrak
Penelitian ini bertujuan untuk mencari Pengaruh Modal Psikologis, Karakteristik Wirausaha, Modal Usaha dan Startegi Pemasaran terhadap Perkembangan Usaha UMKM di Kecamatan Buleleng Tahun 2017. Penelitian ini merupakan penelitian asosiatif, Objek yang akan diteliti adalah UMKM yang ada di Kecamatan Buleleng. Adapun berdasarkan data dari Pemkab Buleleng jumlah dari UMKM Kecamatan Buleleng untuk tahun 2016 periode Januari sampai dengan Oktober berjumlah 276 UMKM. Jenis data yang digunakan dalam penelitian ini adalah kuantitatif sedangkan metode pengumpulan data menggunakan koesioner yang sudah d uji validitas dan reliabilitas terlebih dahulu. Hasil dari penelitian menunjukan variabel modal psikologis $\left(X_{1}\right)$ memiliki tingkat signifikasi sebesar $0,000<0,05$, karakteristik wirausaha $\left(X_{2}\right)$ memiliki tingkat signifikasi sebesar $0,000<0,05$, modal usaha $\left(X_{3}\right)$ memiliki tingkat signifikasi sebesar $0,000<0,05$, strategi pemasaran $\left(X_{4}\right)$ memiliki tingkat signifikasi sebesar $0,000<0,05$, selain itu tingkat signifikan $F$ sebesar $0,000<0,05$ hal ini menunjukan bahwa semua variabel bebas berpengaruh baik secara parsial dan simultan terhadap variabel terikat.
\end{abstract}

Kata kunci: Modal Psikologis, Karakteristik Wirausaha, Modal Usaha Startegi Pemasaran dan UMKM

\begin{abstract}
This research aims to find out the influence of psychological capital, entrepreneurial characteristics, business capital and marketing strategies on the development of UMKM in Buleleng sub-district in 2017. This research is associative research, the object to be studied is the UMKM in Buleleng sub-district. As for data from the Buleleng Regency Government, the number of UMKM in Buleleng District for the period of January to October totaled 276 UMKM. The type of data used in this research is quantitative while the data collection method uses questionnaire which has been tested for validity and reliability first. The results of the research show that the psychological capital variable (X1) has a significance level of $0.000<0.05$, the characteristics of entrepreneurship (X2) have a significance level of $0.000<0.05$, business capital (X3) has a significance level of $0.000<0.05$, Marketing strategy (X4) has a significance level of $0,000<0,05$, besides that the significant level of $F$ is 0,000 $<0,05$. This shows that all independent variables influence both partially and simultaneously on the dependent variable.
\end{abstract}

Keywords: Psychological Capital, Entrepreneurial Characteristics, Business Capital Marketing Strategy and UMKM 


\section{PENDAHULUAN}

Perkembangan UMKM menjadi sesuatu yang harus di jaga serta ditingkatkan setiap tahunnya sejalan dengan perkembangan perekonomian yang mengalami naik dan turun dalam beberapa tahun ke belakang. Menurut Bank Indonesia (2015) dijelaskan bahwa UMKM memegang peranan penting dalam perekonomian di Indonesia. Hal ini ditunjukkan dengan fakta UMKM telah terbukti tidak terpengaruh terhadap krisis. Ketika krisis menerpa pada periode tahun 1997 - 1998, hanya UMKM yang mampu tetap berdiri kokoh. Usaha Mikro, Kecil, dan Menengah telah mampu membuktikan eksistensinya dalam perekonomian di Indonesia. Ketika badai krisis moneter melanda Indonesia di tahun 1998 usaha berskala kecil dan menengah yang relatif mampu bertahan dibandingkan perusahaan besar. Karena mayoritas usaha berskala kecil tidak terlalu tergantung pada modal besar atau pinjaman dari luar dalam mata uang asing. Sehingga, ketika ada fluktuasi nilai tukar, perusahaan berskala besar yang secara umum selalu berurusan dengan mata uang asing adalah yang paling berpotensi mengalami imbas krisis. Data Badan Pusat Statistik memperlihatkan, pasca krisis ekonomi tahun 1997-1998 jumlah UMKM tidak berkurang, justru meningkat terus, bahkan mampu menyerap 85 juta hingga 107 juta tenaga kerja sampai tahun 2012. UMKM memiliki proporsi sebesar 99,99\% dari total keseluruhan pelaku usaha di Indonesia atau sebanyak 56,54 juta unit. Selain hal fakta diatas Bank Indonesia (2015) memaparkan beberapa kontribusi dari UMKM yang tidak bisa dipandang sebelah mata yaitu sebagai tulang punggung perekonomian nasional karena merupakan populasi pelaku usaha dominan (99,9\%), menghasilkan PDB sebesar 59,08\% (Rp4.869,57 Triliun), dengan laju pertumbuhan sebesar $6,4 \%$ pertahun menyumbang volume ekspor mencapai 14,06\% (Rp166,63 triliun) dari total ekspor nasional, pembentukan Modal Tetap Bruto (PMTB) nasional sebesar $52,33 \%$ (Rp830,9 triliun), secara geografis tersebar di seluruh tanah air, di semua sektor, wadah untuk penciptaan wirausaha baru, ketergantungan pada komponen impor yang minimal. Melihat beberapa fakta tersebut maka perkembangan UMKM harus tetap dijaga dan ditingkatkan karena memberikan kontribusi positif terhadap perekonomian Indonesia. Berdasarkan data dari Kementerian Koperasi dan UMKM perkembangan dari tahun 2007 sampai dengan tahun 2012 terus mengalami peningkatan, dari tahun 20072008 terjadi peningkatan sebanyak 1.355.164, tahun 2008-2009 meningkat sebanyak 1.350.545, di tahun 2009-2010 terjadi peningkatan sebesar 1.382.867, tahun 2010-2011 meningkat sebanyak 1.382.162 dan di tahun 2011-2012 meningkat sebesar 1.263.999. peningkatan iklim usaha UMKM telah didukung oleh pemerintah berupa pembuatan kebijakan mengenai UMKM yaitu UU No. 20 Tahun 2008 tentang UMKM. Dengan adanya peraturan yang menjadi payung hukum, gerak UMKM menjadi semakin leluasa. Sehingga dapat diperkirakan dengan adanya dukungan dari pemerintah maka akan dapat meningkatkan jumlah UMKM yang ada di Indonesia. Dijelaskan secara luas bahwa UMKM berperan dalam perekonomian Indonesia, secara lebih sempit bahwa UMKM juga berperan dalam perekonomian Bali, menurut data yang dihimpun dari Forum Komunitas UMKM (2016) dijelaskan bahwa UMKM merupakan salah satu pilar yang turut mendukung perekonomian Bali selama ini yang ditopang oleh industri pariwisata yang dimotori oleh tiga lapangan usaha terbesar yaitu akomodasi makan minum (akmamin) dengan pangsa sebesar $23 \%$, pertanian dengan pangsa sebesar $15 \%$ dan konstruksi $9 \%$. Secara khususnya di Kabupaten Buleleng melalui data yang dihimpun dari Antaranews (2016) yang menyatakan bahwa Bupati Buleleng, Bali, Putu Agus Suradnyana berkomitmen meningkatkan sektor usaha mikro kecil dan menengah (UMKM) mengatasi permasalahan pengangguran di daerah itu melalui pameran dan festival budaya. Dukungan yang diberikan pemerintah dalam peningkatan UMKM dari tingkat tertinggi sampai dengan tingkat 
paling kecil akan dapat meningkatkan pertumbuhan UMKM.

Semakin tingginya pelaku usaha UMKM akan memberikan dampak tertentu bagi pelaku wirausaha UMKM, salah satu dampak yang akan dihadapi adalah dari sisi pesaing, semakin banyaknya UMKM yang bermunculan akan meningkatkan pesaing. Selain dari sisi pesaing, terdapat beberapa hal yang akan dihadapi oleh pelaku wirausaha, seperti penelitian yang dilakukan oleh Purwanti (2012), yang menyatakan bahwa meskipun imbalan dalam kewirausahaan menggiurkan, tapi ada juga biaya yang berhubungan dengan kepemilikan bisnis tersebut. Memulai dan mengoperasikan bisnisnya sendiri, memerlukan kerja keras, menyita banyak waktu dan membutuhkan kekuatan emosi. Wirausaha mengalami tekanan pribadi yang tidak menyenangkan seperti kebutuhan untuk menginvestasikan lebih banyak waktu dan tenaganya. Banyak wirausaha menggambarkan kariernya menyenangkan, tetapi sangat menyita segalanya. Tekanan menjadi hal yang akan dihadapi oleh pelaku wirausaha, namun berdasarkan data dari Bank Indonesia (2015) menyatakan bahwa permasalahan UMKM dalam bidang modal adalah sekitar 60-70\% UMKM belum mendapat akses atau pembiayaan perbankan, dalam bidang Sumber Daya Manusia yaitu kurangnya pengetahuan mengenai teknologi produksi terbaru dan cara menjalankan quality control terhadap produk, kemampuan membaca kebutuhan pasar masih belum tajam, pemasaran produk masih mengandalkan cara sederhana mouth to mouth marketing, dari sisi kuantitas, belum dapat melibatkan lebih banyak tenaga kerja karena keterbatasan kemampuan menggaji, karena pemilik UMKM masih sering terlibat dalam persoalan teknis, sehingga kurang memikirkan tujuan atau rencana strategis jangka panjang usahanya. Selain permasalahan tersebut, hal lain yang memperkuat bahwa UMKM harus memiliki kesiapan dalam mengatasi pertumbuhan UMKM adalah berdasarkan data dari Bank Indonesia (2015) disebutkan bahwa karakteristik dari UMKM adalah kualitasnya belum standar, desain produknya terbatas, jenis produknya terbatas, kapasitas dan daftar harga produknya terbatas, bahan baku kurang terstandar, kontinuitas produk tidak terjamin. Karakteristik UMKM dan permasalah UMKM tersebut nantinya akan dapat menyebabkan kemungkinan terakhir akan terjadi yaitu kebangkrutan dari UMKM yang dijalankan.

Untuk dapat mengatasi kemungkinan kebangkrutan tidak terjadi maka dibutuhkan beberapa hal yang harus dimiliki oleh seorang wirausaha. Hal pertama yang harus dimiliki adalah modal psikologis. Seperti hasil penelitian dari Samir dan Larso (2011) yang menyatakan bahwa modal psikologis entrepreneur memiliki pengaruh yang paling besar terhadap kinerja UKM. Berdasarkan penelitian dari Dewi (2013) bahwa optimis, mempunyai daya tahan, bekerja keras, mempunyai visi kedepan serta berani mengambil risiko merupakan faktor dalam perkembangan usaha. Sehingga berdasarkan hal tersebut hal yang dapat diukur dari modal psikologis adalah optimis, mempunyai daya tahan, bekerja keras, mempunyai visi kedepan serta berani mengambil risiko. Selain modal psikologis hal lain yang dibutuhkan oleh seorang pelaku wirausaha adalah karakteristik dari UMKM, menurut Purwanti (2012) karakteristik UMKM meliputi indikator, keinginan berprestasi, tanggung jawab pribadi, kemampuan inovasi dan kemampuan manajemen. Dengan memiliki karakteristik tersebut maka akam dapat mempertahankan eksistensi usahanya ditengah tekanan yang dihadapi. Hal ini didukung oleh penelitian dari Purwanti (2012) yang menyatakan bahwa karakteristik wirausaha dapat berpengaruh terhadap perkembangan usahanya , karakteristik wirausaha kebutuhan akan keberhasilan, keinginan mengambil risiko, percaya diri dan keinginan kuat untuk berbisnis. Berdasarkan data Bank Indonesia (2015) permasalahan UMKM dari sisi kuantitas, belum dapat melibatkan lebih banyak tenaga kerja karena keterbatasan kemampuan menggaji. Keterbatasan ini mendorong pelaku UMKM harus menyiapkan modal usaha agar nantinya dapat mengatasi kendala dan 
permasalahan UMKM agar dapat menjaga eksitensinya. Berdasarkan penelitian dari Purwanti (2012) hal yang dapat diukur dari modal usaha adalah modal syarat untuk usaha, besar modal, hambatan sumber modal dan sumber modal dari luar. Permasalahan lainnya yang disebutkan oleh Bank Indonesia (2015) adalah pemasaran produk masih mengandalkan cara sederhana mouth to mouth marketing (pemasaran dari mulut ke mulut). Permasalahan tersebut dapat menjadi penghambat dalam kelangsungan usaha pelaku wirausaha, sehingga dibutuhkan strategi pemasaran yang baik agar dapat menghadapi kendala dari UMKM. Berdasarkan penelitian yang dilakukan oleh Purwanti (2012) hal yang dapat diukur dari strategi pemasaran adalah penentuan harga, penentuan pasar, promosi yang dijalankan, kualitas produk.

Permasalahan UMKM, serta karakteristik UMKM yang masih dipandang negatif serta masih sangat sederhana ditengah gencarnya pemerintah, baik pemerintah tertinggi hingga pemerintah Kabupaten yang melakukan cara untuk meningkatkan iklim UMKM harus dibarengi dengan persiapan yang matang berupa modal psikologis, karakteristik wirausaha, modal usaha dan strategi pemasaran oleh pelaku wirausaha untuk dapat mengembangkan usaha UMKMnya. Hal ini dilakukan untuk menghindari adanya kebangkrutan dari UMKM karena seperti penjelasan dari Bank Indonesia (2015) dijelaskan bahwa UMKM memegang peranan penting dalam perekonomian di Indonesia.

Modal psikologis, karakteristik wirausaha, modal usaha dan strategi pemasaran diharapkan dapat mengatasi pemasalahan UMKM untuk memngembangkan usaha UMKM ditengah tekanan yang dihadapi oleh pelaku wirausaha serta dalam menghadapi pertumbuhan UMKM yang akan terus meningkat.

Penelitian dengan topik ini pernah dilakukan oleh Purwanti (2012) dengan judul penelitian "Pengaruh Karakteristik Wirausaha, Modal Usaha, Strategi Pemasaran Terhadap Perkembangan UMKM Di Desa Dayaan Dan Kalilondo
Salatiga" yang mana dari hasil penelitian tersebut menghasilkan bahwa terdapat pengaruh karakteristik wirausaha terhadap perkembangan usaha UMKM di desa Dayaan dan Kalilondo Salatiga secara signifikan, modal usaha terbukti berpengaruh positif dan signifikan terhadap perkembangan usaha, dan strategi pemasaran tidak berpengaruh terhadap perkembangan UMKM di desa Dayaan dan desa Kalilondo Salatiga. Selain itu Dewi (2013) juga melakukan dengan topik sejenis yaitu dengan judul "Pengaruh Faktor Modal Psikologis, Karakteristik Entrepreneur, Inovasi, Manajemen Sumber Daya Manusia, dan Karakteristik UKM terhadap Perkembangan Usaha Pedagang di Pasar Tradisional (Studi Kasus pada Pedagang Sembako dan Snack di Pasar Peterongan), yang menghasilkan bahwa variabel modal psikologis, karakteristik entrepreuner, inovasi, manajemen sumber daya manusia dan karakteristik UKM mempunyai pengaruh terhadap perkembangan usaha di pasar tradisional Peterongan baik secara parsial maupun secara simultan. Selain itu Kusumaningrum (2015) melakukan penelitian yang sejenis dengan judul Analisis Pengaruh Karakteristik Wirausaha, Modal Usaha, dan Strategi Pemasaran terhadap Pengembangan UMKM di Desa Bendungrejo Kecamatan Berbek Kabupaten Nganjuk" hasil dari penelitian ini adalah ada pengaruh positif signifikan antara variabel karakteristik kewirausahaan, modal usaha dan strategi pemasaran terhadap variabel pengembangan UMKM. Penelitian lain juga dilakukan oleh Putri, dkk (2014) dengan judul Pengaruh Karakteristik Kewirausahaan, Modal Usaha dan Peran Business Development Service terhadap Pengembangan Usaha (Studi pada Sentra Industri Kerupuk Desa Kedungrejo Sidoarjo Jawa Timur), yang mana menghasilkan bahwa ada pengaruh karakteristik kewirausahaan, modal usaha dan peran business development service terhadap pengembangan usaha.

Motivasi yang mendasari penelitian ini adalah bahwa penelitian dilakukan dengan tambahan variabel dengan penelitian yang 
pernah dilakukan oleh Purwanti (2012), Kusumaningrum (2015) yang mengambil tiga variabel yaitu karakteristik wirausaha, modal usaha dan strategi pemasaran, dan tambahan variabel dari Dewi (2013) berupa modal psikologis. Serta untuk menganalisis kembali kesenjangan hasil yang didapat dari Purwanti (2012) dan Kusumaningrum (2015) mengenai pengaruh variabel strategi pemasaran terhadap perkembangan usaha UMKM. Selain itu penelitian ini dilakukan pada tahun yang berbeda yaitu pada tahun 2018, serta dilakukan di lokasi yang berbeda yaitu di Kecamatan Buleleng.

Pemilihan Kecamatan Buleleng dikarenakan seperti data yang dihimpun dari Antaranews (2016) bahwa Bupati Buleleng akan berusaha meningkatkan pertumbuhan UMKM melalui pameran dan festival budaya sehingga dengan hal tersebut dapat meningkatkan iklim pertumbuhan UMKM yang akan berpengaruh terhadap tekanan yang akan dihadapi oleh pelaku wirausaha di Kecamatan Buleleng.

\section{METODE}

Penelitian ini merupakan penelitian asosiatif yang bertujuan untuk mengetahui hubungan dua variabel atau lebih. Tujuan dari penelitian ini adalah untuk menguji pengaruh dari modal psikologis, karakteristik wirausaha, modal usaha dan strategi pemasaran terhadap perkembangan usaha UMKM di Kecamatan Buleleng tahun 2016. Adapun data yang digunakan dalam penelitian ini adalah data primer, yang diperoleh dengan menggunakan kuisioner kepada responden. Uji kualitas data yang digunakan adalah dengan uji validitas dan reliabilitas, serta untuk metode analisis data menggunakan uji asumsi klasik yang terdiri dari uji normalitas, uji multikolonierietas dan uji heteroskedastisitas, serta metode analisis data lain yang digunakan yaitu, analisis regresi linier berganda, analisis determinasi, dan uji hipotesis yang terdiri dari uji T dan Uji F.

Objek yang akan diteliti adalah UMKM yang ada di Kecamatan Buleleng. Adapun berdasarkan data dari Pemkab
Buleleng jumlah dari UMKM Kecamatan Buleleng untuk tahun 2016 periode Januari sampai dengan Oktober berjumlah 276 UMKM. Sampel dari penelitian ini diambil dengan teknik pengambilan sampel menggunakan probability sampling dan besarnya sampel menggunakan rumus Slovin dengan tingkat kesalahan $10 \%$. Berikut perhitungannya

Dimana:

$\mathrm{n}$ : jumlah elemen /anggota sampel

$\mathrm{N}$ : jumlah elemen /anggota populasi

e : error level (tingkat kesalahan)

Dari hasil perhitungan di atas didapatkan hasil jumlah sampel wirausahawan yang akan dikirimkan kuisioner adalah 73 responden. $\mathrm{Di}$ Kecamatan Buleleng terdapat 29 desa, sehingga besarnya sampel dilakukan dengan alokasi proporsional.

Jenis data yang digunakan dalam penelitian ini adalah kuantitatif yaitu jenis data yang berupa angka-angka yang dapat dihitung atau diukur secara nyata seperti perhitungan sampel jumlah wirausahawan dan jumlah jawaban responden terhadap kuisioner yang diberikan. Sumber data yang digunakan dalam penelitian ini adalah sumber data primer yaitu data yang diperoleh secara langsung dari perusahaan atau organisasi yang teliti. Data penelitian yang dikumpulkan pada penelitian ini diperoleh dari kuisioner yang disebarkan kepada responden yaitu wirausahawan pada Kecamatan Buleleng. Metode pengumpulan data yang digunakan dalam penelitian ini adalah metode kuisioner yaitu cara pengumpulan data dengan menggunakan daftar pertanyaan yang disebar kepada responden dan dimintai keterangan terhadap sesuatu yang dialami. Tipe pada kuisioner ini berupa skala linkert dengan rentang jawaban 1-5. Jawaban yang didapat akan dibuat skor dengan kriteria penilaian yaitu nilai (1) untuk jawaban sangat tidak setuju, nilai (2) untuk jawaban tidak setuju, nilai (3) untuk jawaban cukup 
setuju, nilai (4) untuk jawaban setuju, dan nilai (5) untuk jawaban sangat setuju.

Dalam penelitian ini juga menggunakan uji asumsi klasik untuk mendukung keakuratan dari data yang di sajikan dimana uji asumsi klasik yang digunakan adalah uji Multikolonieritas untuk menguji apakah model regresi ditemukan adanya korelasi antar variabel bebas (Variabel Independen), uji Heteroskedastisitas untuk menguji apakah dalam model regresi terjadi ketidaksamaan variance dari residual satu pengamatankepengamatan yang lain, uji Normalitas untuk menguji apakah model regresi, variabelpengganggu atau residual memiliki distribusi normal, dan Analisis regresi linier sederhana didasarkan pada hubungan fungsional ataupun kasual suatu variabel independen dengan satu variabel dependen.

\section{HASIL DAN PEMBAHASAN \\ Hasil}

Uji normalitas dalam penelitian ini menggunakan statistik KolgomorovSmirnov dengan kriteria yang ditentukan yaitu membandingkan nilai Asymp. Sig (2Tailed) dengan nilai alpha yang ditentukan yaitu 5\%. Apabila nilai Asymp. Sig (2Tailed) > 0,05 maka data yang telah diuji berasal dari populasi yang terdistribusi secara normal. Berdasarkan hasil uji normalitas diatas dapat dilihat nilai Asymp. Sig. (2-tailed) sebesar 0,798 > 0,05 maka dapat simpulkan bahwa data-data penelitian telah berdistribusi normal.

\begin{tabular}{|c|c|c|}
\hline \multicolumn{3}{|c|}{ One-Sample Kolmogorov-Smirnov Test } \\
\hline & & $\begin{array}{l}\text { Unstanda } \\
\text { rdized } \\
\text { Residual }\end{array}$ \\
\hline \multicolumn{2}{|l|}{$\mathrm{N}$} & 73 \\
\hline \multirow[b]{2}{*}{$\begin{array}{l}\text { Normal } \\
\text { Parameters }\end{array}$} & Mean & $\begin{array}{r}0,000000 \\
0\end{array}$ \\
\hline & $\begin{array}{l}\text { Std. } \\
\text { Deviatio } \\
n\end{array}$ & $\begin{array}{r}0,696115 \\
49\end{array}$ \\
\hline \multirow{3}{*}{$\begin{array}{l}\text { Most Extreme } \\
\text { Differences }\end{array}$} & Absolute & 0,076 \\
\hline & Positive & 0,062 \\
\hline & Negative & $-0,076$ \\
\hline \multicolumn{2}{|c|}{ Kolmogorov-Smirnov Z } & 0,646 \\
\hline \multicolumn{2}{|c|}{ Asymp. Sig. (2-tailed) } & 0,798 \\
\hline
\end{tabular}

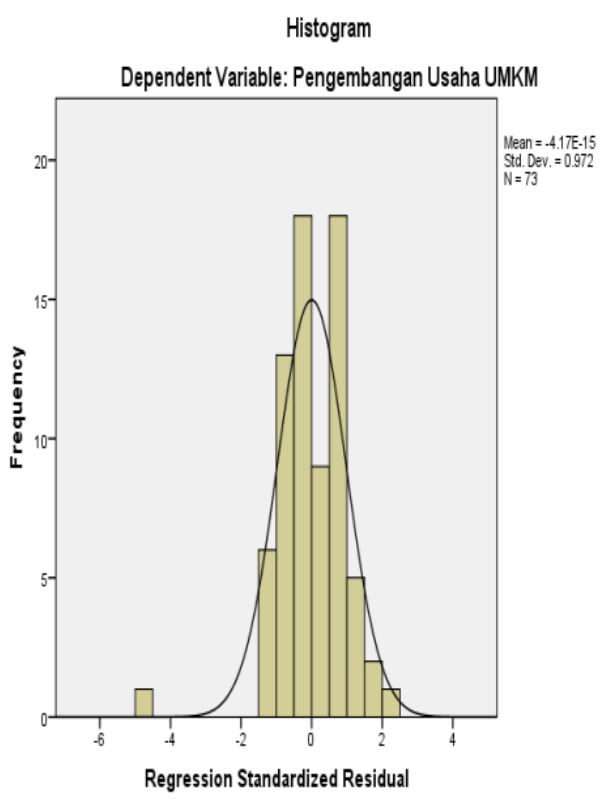

a. Test distribution is Normal.

b. Calculated from data.

Gambar 1. Hasil Uji Normalitas

Berdasarkan hasil uji multikolonieritas menunjukkan nilai VIF $\leq 10$ dan nilai Tolerence $\geq 0,10$ maka dapat disimpulkan bahwa tidak ada multikolinearitas dalam model regresi.

Kriteria yang digunakan untuk menunjukkan adanya 
multikolinearitas adalah nilai tolerance $>0,10$ atau nilai $\mathrm{VIF}<10$ dengan tingkat kolinearitas 0,05 .
Hasil uji multikolinearitas pada variabel bebas penelitian ini sbb:

Tabel 1. Hasil uji multikolonieritas

\begin{tabular}{|c|c|c|c|c|}
\hline No & Variabel & Tolerance & VIF & Keterangan \\
\hline 1 & Modal Psikologis (X1) & 0,599 & 1,668 & $\begin{array}{c}\text { Tidak terjadi } \\
\text { multikolinearitas }\end{array}$ \\
\hline 2 & $\begin{array}{l}\text { Karakteristik Wirausaha } \\
(\mathrm{X} 2)\end{array}$ & 0,422 & 2,371 & $\begin{array}{c}\text { Tidak terjadi } \\
\text { multikolinearitas }\end{array}$ \\
\hline 3 & Modal Usaha (X3) & 0,513 & 1,950 & $\begin{array}{c}\text { Tidak terjadi } \\
\text { multikolinearitas }\end{array}$ \\
\hline 4 & Strategi Pemasaran (X4) & 0,710 & 1,408 & $\begin{array}{c}\text { Tidak terjadi } \\
\text { multikolinearitas }\end{array}$ \\
\hline
\end{tabular}

Berdasarkan hasil perhitungan yang ditunjukan pada tabel 2 dapat disimpulkan bahwa nilai probabilitas antara data pengamatan dengan residual absolutnya untuk masing-masing variabel yaitu X1 $(0,142), X 2(0,949), X 3(0,323), X 4$ $(0,937)$ semua diatas taraf signifikan yang ditetapkan yaitu $5 \%$ atau 0,05 . Oleh karena itu penelitian ini telah terbebas dari indikasi heteroskedastisitas.

Tabel 2. Hasil heteroskedastisitas

\section{Coefficients $^{\mathrm{a}}$}

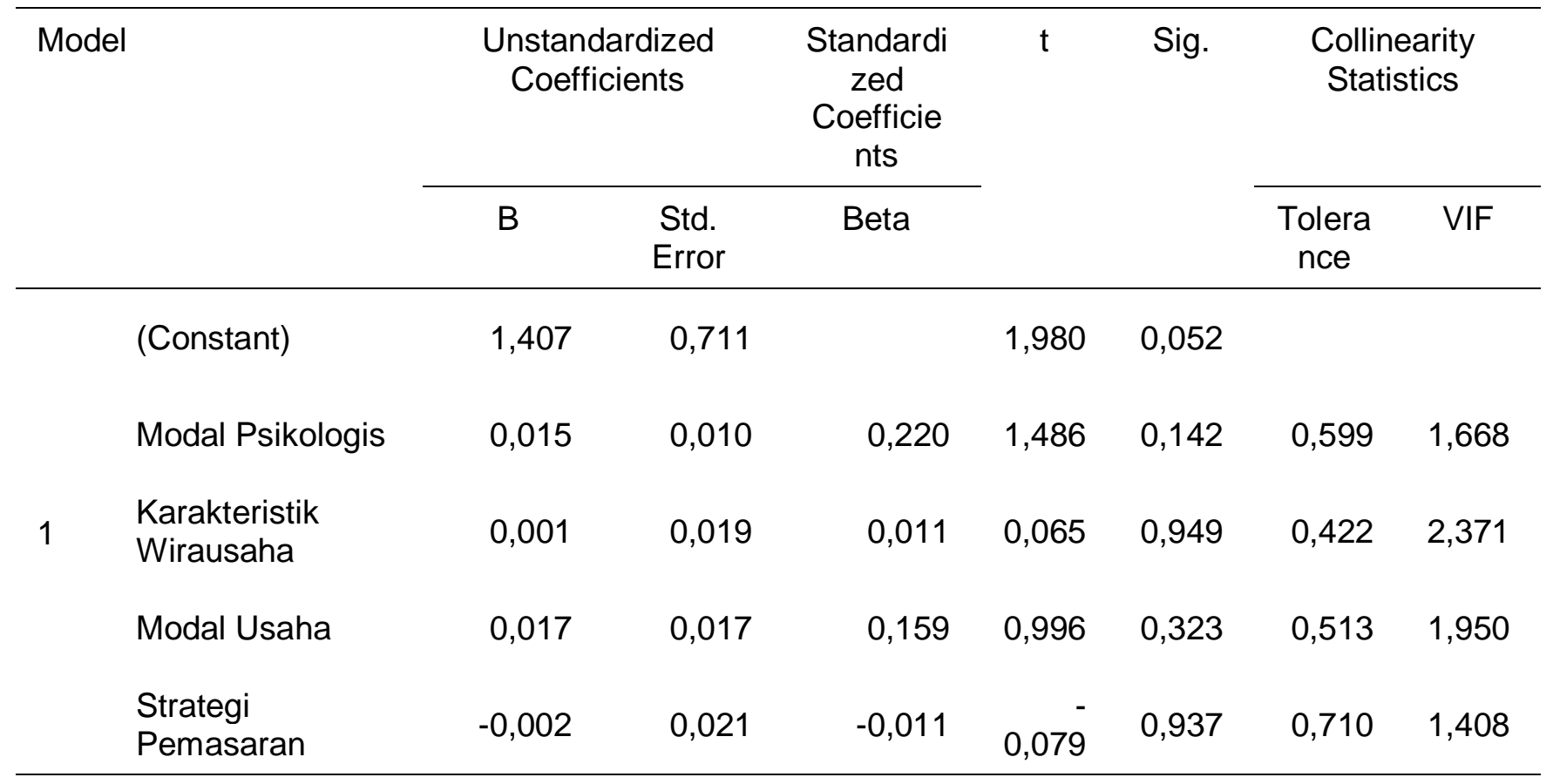

a. Dependent Variable: Ares

Berdasarkan hasil persamaan regresi yang ditunjukan pada tabel 3 di bawah dapat dijelaskan pola pengaruh Modal Psikologis (X1), Karakteristik 
Wirausaha (X2), Modal Usaha (X3), Strategi Pemasaran (X4) terhadap Pengembangan Usaha UMKM sebagai berikut: Nilai konstan sebesar 10,279 menyatakan bahwa apabila terjadi variabel independen Modal Psikologis (X1), Karakteristik Wirausaha (X2), Modal Usaha (X3), Strategi Pemasaran (X4) sama dengan nol, maka variabel dependen Pengembangan Usaha UMKM (Y) adalah sebesar 10,279 . Nilai koefisien $\beta_{1}=0,165$ menunjukkan bahwa terdapat pengaruh positif antara variabel Modal Psikologis (X1), terhadap Pengembangan Usaha UMKM (Y) sebesar 0,165. Hal ini berarti apabila variabel independen Modal Psikologis (X1), naik sebesar 1 satuan dengan asumsi bahwa variabel bebas lainnya konstan, maka variabel terhadap Pengembangan Usaha UMKM (Y) akan mengalami kenaikan sebesar 0,165 satuan. Nilai koefisien $\beta_{2}=0,130$ menunjukkan bahwa terdapat pengaruh positif antara variabel Karakteristik Wirausaha (X2), terhadap Pengembangan Usaha UMKM (Y) sebesar 0,130. Hal ini berarti apabila variabel independen
Karakteristik Wirausaha (X2), naik sebesar 1 satuan dengan asumsi bahwa variabel bebas lainnya konstan, maka variabel terhadap Pengembangan Usaha UMKM (Y) akan mengalami kenaikan sebesar 0,130 satuan. Nilai koefisien $\beta_{3}=0,158$ menunjukkan bahwa terdapat pengaruh positif antara variabel Modal Usaha (X3), terhadap Pengembangan Usaha UMKM (Y) sebesar 0,130. Hal ini berarti apabila variabel independen Modal Usaha (X3), naik sebesar 1 satuan dengan asumsi bahwa variabel bebas lainnya konstan, maka variabel terhadap Pengembangan Usaha UMKM (Y) akan mengalami kenaikan sebesar 0,158 satuan. Nilai koefisien $\beta_{4}=0,243$ menunjukkan bahwa terdapat pengaruh positif antara variabel Strategi Pemasaran (X4), terhadap Pengembangan Usaha UMKM (Y) sebesar 0,243 . Hal ini berarti apabila variabel independen Strategi Pemasaran (X4), naik sebesar 1 satuan dengan asumsi bahwa variabel bebas lainnya konstan, maka variabel terhadap Pengembangan Usaha UMKM (Y) akan mengalami kenaikan sebesar 0,243 satuan.

Tabel 3. Hasil Persamaan Regresi

Coefficients $^{a}$

\begin{tabular}{|c|c|c|c|c|c|c|c|}
\hline \multirow[t]{2}{*}{ Model } & \multicolumn{2}{|c|}{$\begin{array}{l}\text { Unstandardized } \\
\text { Coefficients }\end{array}$} & \multirow{2}{*}{$\begin{array}{c}\begin{array}{c}\text { Standard } \\
\text { ized } \\
\text { Coefficie } \\
\text { nts }\end{array} \\
\text { Beta }\end{array}$} & \multirow[t]{2}{*}{$\mathrm{t}$} & \multirow[t]{2}{*}{ Sig. } & \multicolumn{2}{|c|}{$\begin{array}{l}\text { Collinearity } \\
\text { Statistics }\end{array}$} \\
\hline & B & $\begin{array}{l}\text { Std. } \\
\text { Error }\end{array}$ & & & & $\begin{array}{c}\text { Tolera } \\
\text { nce }\end{array}$ & VIF \\
\hline (Constant) & $\begin{array}{r}10,27 \\
9\end{array}$ & 1,111 & & $\begin{array}{r}9,25 \\
4\end{array}$ & $\begin{array}{r}0,00 \\
0\end{array}$ & & \\
\hline Modal Psikologis & 0,165 & 0,016 & 0,432 & $\begin{array}{r}10,1 \\
30\end{array}$ & $\begin{array}{r}0,00 \\
0\end{array}$ & 0,599 & $\begin{array}{r}1,6 \\
68\end{array}$ \\
\hline $\begin{array}{l}\text { Karakteristik } \\
\text { Wirausaha }\end{array}$ & 0,130 & 0,030 & 0,220 & $\begin{array}{r}4,33 \\
0\end{array}$ & $\begin{array}{r}0,00 \\
0\end{array}$ & 0,422 & $\begin{array}{r}2,3 \\
71\end{array}$ \\
\hline Modal Usaha & 0,158 & 0,027 & 0,272 & $\begin{array}{r}5,90 \\
4\end{array}$ & $\begin{array}{r}0,00 \\
0\end{array}$ & 0,513 & $\begin{array}{r}1,9 \\
50\end{array}$ \\
\hline $\begin{array}{l}\text { Strategi } \\
\text { Pemasaran }\end{array}$ & 0,243 & 0,033 & 0,287 & $\begin{array}{r}7,31 \\
7\end{array}$ & $\begin{array}{r}0,00 \\
0\end{array}$ & 0,710 & $\begin{array}{r}1,4 \\
08\end{array}$ \\
\hline
\end{tabular}

a. Dependent Variable: Pengembangan Usaha UMKM 
Adapun persamaan regresi linear berganda dalam penelitian ini adalah sebagai berikut.

$Y=10,279+0,165 X_{1}+0,130 X_{2}+0,158 X_{3}$

$+0,243 X_{4}+e$

Dimana:

$\mathrm{Y}=$ Pengembangan Usaha

$\mathrm{X}_{1}=$ Modal Psikologis

$\mathrm{X}_{2}=$ Karakteristik Wirausaha

$\mathrm{X}_{3}=$ Modal Usaha

$\mathrm{X}_{4}=$ Strategi Pemasaran

$\mathrm{e}_{\mathrm{i}} \quad=$ Standard error
Berdasarkan hasil penghitungan determinasi pada tabel 4 di bawah diperoleh koefisien determinasi sebesar 0,922, menunjukkan bahwa variabel Modal Psikologis (X1), Karakteristik Wirausaha (X2), Modal Usaha (X3), Strategi Pemasaran (X4) mempunyai kontribusi sebesar 92,2\% terhadap terhadap Pengembangan Usaha UMKM (Y) sedangkan sisanya $7,8 \%$ dipengaruhi oleh faktor lain yang tidak diteliti.

Tabel 4. Hasil penghitungan determinasi

Model Summary

\begin{tabular}{llrrrr}
\hline Model & $R$ & R Square & $\begin{array}{c}\text { Adjusted } R \\
\text { Square }\end{array}$ & $\begin{array}{l}\text { Std. Error of } \\
\text { the Estimate }\end{array}$ & Durbin-Watson \\
\hline 1 & $0,962^{\mathrm{a}}$ & 0,926 & 0,922 & 0,716 & 1,666 \\
\hline
\end{tabular}

a. Predictors: (Constant), Strategi Pemasaran, Modal Usaha, Modal Psikologis, Karakteristik Wirausaha

b. Dependent Variable: Pengembangan Usaha UMKM

Untuk mengetahui ada tidaknya pengaruh signifikan dalam uji $\mathrm{F}$ dilakukan dengan membandingkan nilai antara $F_{\text {hitung }}$ dengan nilai $F_{\text {tabel }}$ atau dengan membandingkan nilai signifikansi dari pengujian SPSS apakah nilai signifikan tersebut lebih besar atau lebih kecil dari standar statistik yakni 0,05. Hasil uji simultan variabel penelitian ini diperoleh hasil besarnya nilai $F_{\text {hitung }}$ adalah 212, 436 lebih besar dari $F_{\text {tabel }} 2,50$ yang artinya $H_{0}$ ditolak dan $\mathrm{H}_{5}$ diterima. Selain itu, tingkat signifikan $F$ sebesar $0,000<0,05$. Hal ini berarti bahwa terdapat pengaruh secara simultan.

Tabel 5. Hasil Uji F

ANOVA $^{\mathrm{a}}$

\begin{tabular}{|c|c|c|c|c|c|c|}
\hline \multicolumn{2}{|l|}{ Model } & $\begin{array}{l}\text { Sum of } \\
\text { Squares }\end{array}$ & $\mathrm{df}$ & $\begin{array}{l}\text { Mean } \\
\text { Square }\end{array}$ & $F$ & Sig. \\
\hline \multirow{3}{*}{1} & $\begin{array}{l}\text { Regressio } \\
\mathrm{n}\end{array}$ & 435,987 & 4 & 108,997 & 212,436 & $0,000^{\mathrm{b}}$ \\
\hline & Residual & 34,890 & 68 & 0,513 & & \\
\hline & Total & 470,877 & 72 & & & \\
\hline
\end{tabular}


a. Dependent Variable: Pengembangan Usaha UMKM

b. Predictors: (Constant), Strategi Pemasaran, Modal Usaha, Modal Psikologis,

Karakteristik Wirausaha

Berdasarkan hasil analisis dapat diketahui tingkat signifikan masing-masing variabel bebas, yaitu: Variabel Modal Psikologis $\left(\mathrm{X}_{1}\right)$ memiliki tingkat signifikasi sebesar $0,000<0,05$ dan memiliki koefisien positif sebesar 0,165 maka $\mathrm{H}_{0}$ ditolak dan $\mathrm{H}_{1}$ diterima. Selain itu, Modal Psikologis $\left(\mathrm{X}_{1}\right)$ memiliki thitung lebih besar dari $t_{\text {tabel, }}$ yaitu sebesar $10,130>1,995$. Hal ini berarti sesuai dengan $H_{1}$ yang menyatakan bahwa variabel Modal Psikologis (X1) berpengaruh secara positif signifikan terhadap Pengembangan Usaha UMKM (Y). Variabel Karakteristik Wirausaha $\left(X_{2}\right)$ memiliki tingkat signifikasi sebesar $0,000<0,05$ dan memiliki koefisien positif sebesar 0,130 maka $\mathrm{H}_{0}$ ditolak dan $\mathrm{H}_{2}$ diterima. Selain itu, Karakteristik Wirausaha $\left(\mathrm{X}_{2}\right)$ memiliki thitung lebih besar dari $t_{\text {tabel, }}$ yaitu sebesar 4,330 > 1,995. Hal ini berarti sesuai dengan $\mathrm{H}_{2}$ yang menyatakan bahwa variabel Karakteristik Wirausaha $\left(\mathrm{X}_{2}\right)$ berpengaruh secara positif signifikan terhadap
Pengembangan Usaha UMKM (Y). Variabel Modal Usaha $\left(X_{3}\right)$ memiliki tingkat signifikasi sebesar $0,000<0,05$ dan memiliki koefisien positif sebesar 0,158 maka $\mathrm{H}_{0}$ ditolak dan $\mathrm{H}_{3}$ diterima. Selain itu, Modal Usaha $\left(X_{3}\right)$ memiliki thitung lebih besar dari $t_{\text {tabel}}$, yaitu sebesar 5,904 $>1,995$. Hal ini berarti sesuai dengan $\mathrm{H}_{3}$ yang menyatakan bahwa variabel Modal Usaha $\left(\mathrm{X}_{3}\right)$ berpengaruh secara positif signifikan terhadap Pengembangan Usaha UMKM $(Y)$. Variabel Strategi Pemasaran $\left(X_{4}\right)$ memiliki tingkat signifikasi sebesar $0,000<$ 0,05 dan memiliki koefisien positif sebesar 0,243 maka $\mathrm{H}_{0}$ ditolak dan $\mathrm{H}_{4}$ diterima. Selain itu, Strategi Pemasaran $\left(\mathrm{X}_{4}\right)$ memiliki thitung lebih besar dari $t_{\text {tabel, }}$ yaitu sebesar 7,317>1,995. Hal ini berarti sesuai dengan $\mathrm{H}_{4}$ yang menyatakan bahwa variabel Strategi Pemasaran $\left(\mathrm{X}_{4}\right)$ berpengaruh secara positif signifikan terhadap Pengembangan Usaha UMKM (Y).

Tabel 6. Hasil Uji t

\begin{tabular}{|c|c|c|c|c|c|}
\hline \multirow[t]{2}{*}{ Model } & \multicolumn{2}{|c|}{$\begin{array}{l}\text { Unstandardized } \\
\text { Coefficients }\end{array}$} & \multirow{2}{*}{$\begin{array}{c}\begin{array}{c}\text { Standardize } \\
\text { d }\end{array} \\
\text { Coefficients }\end{array}$} & \multirow[t]{2}{*}{$\mathrm{t}$} & \multirow[t]{2}{*}{ Sig. } \\
\hline & B & $\begin{array}{l}\text { Std. } \\
\text { Error }\end{array}$ & & & \\
\hline (Constant) & $\begin{array}{r}100,27 \\
9\end{array}$ & 1,111 & & 9,254 & 0,000 \\
\hline Modal Psikologis & 0,165 & 0,016 & 0,432 & 10,130 & 0,000 \\
\hline Karakteristik Wirausaha & 0,130 & 0,030 & 0,220 & 4,330 & 0,000 \\
\hline Modal Usaha & 0,158 & 0,027 & 0,272 & 5,904 & 0,000 \\
\hline Strategi Pemasaran & 0,243 & 0,033 & 0,287 & 7,317 & 0,000 \\
\hline
\end{tabular}




\section{SIMPULAN DAN SARAN Simpulan}

Berdasarkan perhitungan yang telah dilakukan dapat dinyatakan bahwa: Modal psikologis berpengaruh positif dan signifikan terhadap perkembangan usaha UMKM di Kecamatan Buleleng. Sehingga semakin besar modal psikologis pelaku UMKM maka semakin tinggi pula perkembangan usaha UMKM di Kecamatan Buleleng. Karakteristik wirausaha berpengaruh positif dan signifikan terhadap perkembangan usaha UMKM di Kecamatan Buleleng. Sehingga semakin besar karakteristik wirausaha semakin tinggi pula perkembangan usaha UMKM di Kecamatan Buleleng. Modal usaha berpengaruh posistif dan signifikan terhadap perkembangan usaha UMKM di Kecamatan Buleleng. Sehingga semakin besar modal usaha semakin tinggi perkembangan usaha UMKM di Kecamatan Buleleng. Strategi pemasaran berpengaruh positif dan signifikan terhadap perkembangan usaha UMKM di Kecamatan Buleleng. Sehingga semakin besar strategi pemasaran semakin tinggi perkembangan usaha UMKM di Kecamatan Buleleng.

\section{Saran}

Adapun saran yang dapat diberikan oleh peneliti adalah sebagai berikut: Diharapkan pemerintah daerah dapat meningkatkan iklim wirausaha yang ada di Kecamatan Buleleng melalui pelatihanpelatihan sehingga nantinya dapat meningkatkan minat dan memotivasi para calon wirausaha untuk lebih berani dalam memulai dunia usaha. Bagi para pelaku UMKM di Kecamatan Buleleng untuk dapat meningkatkan motivasi dalam menjalani usahanya sehingga rasa tidak mudah menyerah yang dapat menggangu psikologis pelaku UMKM tidak akan dapat memepengaruhi keinginan yang kuat untuk memajukan usahanya. Bagi peneliti selanjutnya untuk dapat menambahkan variabel lain yang dapat mempengaruhi perkembangan usaha UMKM karena masih banyak variabel lain yang dapat mempengaruhi perkembangan usaha para pelaku UMKM di Kecamatan Buleleng

\section{DAFTAR PUSTAKA}

Antaranews. 2016. Bupati Buleleng Komitmen Tingkatkan UMKM Atasi Pengangguran. Diunduh 1 April 2018.

https://bali.antaranews.com/berita/ 88907/bupati-buleleng-komitmentingkatkan-umkm-atasipengangguran.

Bank Indonesia. 2015. Profil Bisnis Usaha Mikro, Kecil dan Menengah (UMKM). Jakarta.

Dewi, Reni Shinta. 2013. Pengaruh Faktor Modal Psikologis, Karakteristik Entrepreneur, Inovasi, Manajemen Sumber Daya Manusia, dan Karakteristik UKM Terhadap Perkembangan Usaha Pedagang di Pasar Tradisional (Studi Kasus pada Pedagang Sembako dan Snack di Pasar Peterongan). Jurnal Administrasi Bisnis, 2 (1): 29-40.

Forum Komunitas UMKM. 2016. UMKM Berperan Penting dalam Perekonomian Bali. Diunduh 1 April $2018 . \quad$ http://fokusumkm.com/umkm-berperanpenting-dalam-perekonomian-bali/

Kusumaningrum. 2015. Analisis Pengaruh Karakteristik Wirausaha, Modal Usaha, dan Strategi Pemasaran terhadap Pengembangan UMKM di Desa Bendungrejo Kecamatan Berbek Kabupaten Nganjuk. Skripsi. Kediri: Universitas Nusantara PGRI Kediri.

Purwanti, Endang. 2012. Pengaruh Karakteristik Wirausaha, Modal Usaha, Strategi Pemasaran Terhadap Perkembangan UMKM di Desa Dayaan Dan Kalilondo Salatiga. Among Makarti, 5 (9): 1328.

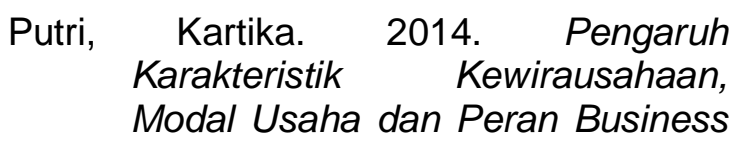


Development Service Terhadap Pengembangan Usaha (Studi Pada Sentra Industri Kerupuk Desa Kedungrejo Sidoarjo Jawa Timur). Working Paper. Semarang: Universitas Diponegoro.

Samir, Alfin dan Dwi Larso. 2011. Identifikasi Faktor-Faktor yang Mempengaruhi Kinerja UKM Catering di Kota Bandung. Jurnal Manajemen Teknologi, 10 (2): 162185. 